\title{
PRODUCTIVITY OF TRITICALE DEPENDING ON THE CONTENT OF PHOTOSYNTHESIZING PIGMENTS AT ANTHESIS
}

B. O. MAZURENKO, Ph. D., assistant at the Department of Plant Science, https://orcid.org/0000-0002-4177-9909

National University of Life and Environmental Sciences of Ukraine e-mail: mazurenko.bohdan@nubip.edu.ua

\begin{abstract}
Photosynthetic pigments play an important role in the accumulation of dry matter and they can be the markers of stress. Change in the ratio of chlorophyll $A$ and $B$ indicates physiological changes and adaptation of the organism to changes of environmental conditions. Sowing terms and application of nitrogen fertilizers are long-term factors, so the content of chlorophylls in the flag leaf indicates long-term adaptation of the photosynthetic system. Establishing a relationship between the chlorophyll content at anthesis and the accumulation of dry matter in posy-anthesis period indicates the varietal response of triticale to fertilization and sowing dates. It was conducted a three-factor field experiment. There are studied two winter and one facultative triticale cultivar, two autumn sowing terms and fertilization system with application the different rates of nitrogen fertilizers in different growth stages. It was found that the content of photosynthetic pigments in each variety varied depending on sowing term and fertilizer system in terms of $\mathrm{mg}$ per $1 \mathrm{~g}$ of dry matter for chlorophyll $A, B$ and the amount of $A+B$. At the same time, the difference between the factors and their interactions was insignificant for the total chlorophyll mass per unit area $(\mathrm{g} / \mathrm{m} 2)$ for chlorophyll $A$ and the amount of $A+B$, but it was significant for chlorophyll $B$ by the fertilizer system factor. This indicates that the main stress signal is chlorophyll $B$, so the ratio of chlorophyll $A$ and $B$ differed significantly depending on this factor. Cla: Clb ratio in the optimal sowing period is 5.3-8.1 in cv. Pidzimok kharkivskiy, 4.8-8.3 in cv. Amur and 5.0-6.7 in cv. Obriy mironivskiy. All cultivars have a strong positive correlation between the chlorophyll content at anthesis and accumulation of dry matter at post-anthesis perion under optimal conditions, but facultative triticale Pidzimok kharkivskiy has a negative correlation with unfavorable, due to increased chlorophyll, without increasing dry matter accumulation. Further study of the relationship between chlorophyll content and the synthesis of primary and secondary metabolites is promising in the study of varietal response to stress and agronomic factors.
\end{abstract}

Key words: chlorophyll, correlation, dry matter, facultative triticale 


\section{Introduction.}

Morphological features of the flag leaf of cereals significantly affect its productivity (Yang et. al., 2016). The basis of the photosynthetic system of the plant are green pigments chlorophyll A and $\mathrm{B}$, which have a similar structure, but differ in the spectrum of waves that absorb (Britton, 1983). Content and ratios of pigments are a varietal feature of cereals (Pryadkina \& Makharinska, 2021), and chlorophyll content is higher and varies greatly in triticale (Arough et al., 2016). Productivity of photosynthesis depends on the amount of these pigments in the plant, and their content in the flag leaf can predict the yield potential (Simpson, 1968).

The fertilizer system has an important effect on plant growth and development, but its impact on chlorophyll content is indirect. Nitrogen concentration in plants is related to chlorophyll content, and therefore indirectly to one of the basic plant physiological processes: photosynthesis (Haboudane et al., 2002; Amaliotis et al., 2004). Cereals have a different requirement to nitrogen in different growth stages (Akhter et al., 2016), so chlorophyll content varies similar (Shadchina \& Dmitrieva, 1995). Chlorophyll content can be a stress indicator in plants under unfavorable conditions or nutrient deficiency (Tejada-Zarco et al., 2004). Nitrogen as a structural element of chlorophyll and its deficiency can impact on photosynthesis and dry matter accumulation (Ray Tucker, 2004).

\section{Materials and methods of research.}

Field experiments were conducted in 2016-2019 in the Right-bank Forrest-Steppe of Ukraine $\left(49^{\circ} 46^{\prime} \mathrm{N}, 30^{\circ} 44\right.$
E). The soil is typical low-humic black, the arable layer of which is characterized by the following agrochemical and agro-physical indices: humus content $-4.31-4.63 \%$; $\mathrm{pH}-7.2$, easily hydrolyzed nitrogen (according to Kornfeld) - 152.3-167.0 mg; $\mathrm{P}_{2} \mathrm{O}_{5}$ in acetic acid extract (according to Chirikov) - 109.0 $142.0 \mathrm{mg}$; exchangeable potassium (according to Chirikov) $-127.0-132.0 \mathrm{mg}$ per $1 \mathrm{~kg}$ of soil.

Field experiment was conducted by 3 -factorial scheme. Factor A is a cultivar, factor B is a sowing term and factor $\mathrm{C}$ is a fertile system. There are Pidzimok kharkivskiy (facultative), Amur (winter) and Obriy mironivkiy (winter) were observed. Each cultivar was sowed in two terms $-2^{\text {nd }}$ and $3^{\text {rd }}$ decade of October. Fertilization system included 4 options. There are $\mathrm{P}_{36} \mathrm{~K}_{72}$ as a fone (B1), and 3 options with different nitrogen fertilizations (B2 $-\mathrm{P}_{36} \mathrm{~K}_{72}+\mathrm{N}_{25(11-13)}$; $\mathrm{B} 3$ $-\mathrm{P}_{36} \mathrm{~K}_{72}+\mathrm{N}_{25(11-13)}+\mathrm{N}_{55(23)} ; \mathrm{B} 4-\mathrm{P}_{36} \mathrm{~K}_{72}$ $+\mathrm{N}_{25(11-13)}+\mathrm{N}_{55(25)}+\mathrm{N}_{20(4)} 5(23)$.

Tillage system included only one plowing after preceding crop harvesting (soybean). Was conducted cultivation on sowing depth $(2-4 \mathrm{~cm})$ before sowing. Triticale was sown with $15-\mathrm{cm}$ inter-row spacing with rate 450 grains per square meter. Weren't applied pesticides during research. The experiment was established in 4 replications. The size of elementary plots was $32 \mathrm{~m}^{2}$ ( $25.2 \mathrm{~m}^{2}$ to harvesting).

10 plants was collected in anthesis and wax ripeness for establishing crop growth rate (Hunt et al., 2002) and chlorophyll content in flag leaf at anthesis. Chlorophyll content was determined by spectrophotometric method and calculating according Wellburn(1994). Statistical elaboration date was done by multifactorial analysis ANOVA in Statistica 13.0. Difference between variant was established by Fisher LSD post-hoc test. 


\section{Results.}

Content of photosynthetic pigments in the flag leaf at anthesis is an important indicator of the productivity potential of triticale. Flag leaf can accumulate almost up to half of the dry matter of the seed under normal conditions, so the increase in its content indicates an increase in assimilation processes. Plants of different sowing terms in a certain phase may have different contents of photosynthetic pigments, have different ratios of chlorophyll species, and their concentration will depend on the structure of the leaf, area and nutrition. Time of anthesis will be different, so the weather conditions will also make their adjustments.

Content of chlorophyll A and B in the dry matter of the flag leaf $(\mathrm{mg} / \mathrm{g})$ varied significantly depending on the variety and sowing period (table 1 and 2). Cultivar is one of the main factors in the variation of chlorophyll A and B, as well as their sum, it is necessary to consider each variety separately.

$\mathrm{Cv}$. Pidzimok kharkivskiy is characterized by a much lower content of chlorophyll A in the flag leaf than other cultivars. Content of chlorophyll A in the variants without nitrogen application and at the rate of $25 \mathrm{~kg} / \mathrm{ha}$ do not differ significantly, because the habitus of plants is similar, and the area of the flag leaf and its weight did not differ significantly. The content of chlorophyll A is significant in the plants of the first sowing term only at the norms of $100 \mathrm{~kg} / \mathrm{ha}$, and such effect was already at the norms of $80 \mathrm{~kg} / \mathrm{ha}$ and $100 \mathrm{~kg} / \mathrm{ha}$ in the second one. That is, the effect of nitrogen was prolonged, the content of chlorophyll B also increased accordingly, but the ratio of $\mathrm{Cl}_{\mathrm{a}}: \mathrm{Cl}_{\mathrm{b}}$ differed significantly, and its low value is evidence of stress.
$\mathrm{Cv}$. Amur has a different reaction to nitrogen fertilization acco $r$ ding to the chlorophyll A content depending on the sowing term. Content of $\mathrm{Cl}_{a}$ is significantly reduced at the rates of application of $80-100 \mathrm{~kg} / \mathrm{ha}$ of nitrogen compared to the options without application $25 \mathrm{~kg} / \mathrm{ha}$ in plants of first sowing term. For other side, content of chlorophyll A increases when nitrogen is applied at the rate of $25-80 \mathrm{~kg} / \mathrm{ha}$, but fertilization at $100 \mathrm{~kg} /$ ha significantly reduces its content.

Cultivar Obriy myironivs k iy was characterized by a much higher content of chlorophyll A than other varieties, although the trends during the first sowing period were similar to cv. Amur, but the nitrogen rate of $100 \mathrm{~kg} / \mathrm{ha}$ had a stimulating effect. During the second sowing period, the chlorophyll content did not have a significant diff e rence between the fone, and rates of 80 and $100 \mathrm{~kg} / \mathrm{ha}$, but significantly decreased at the rate of $25 \mathrm{~kg} / \mathrm{ha}$ of nitrogen.

Chlorophyll content (A and B) differed significantly $\mathrm{b}$ etween cultivars, sowing terms, but the effect of the fertilizer system was a mbiguous (table 2). Content of chlorophyll A (figure 1) in the $\mathrm{cv}$. Amur and cv. Obriy mironivskiy did not differ signific antly, but the content of chlorophyll B was higher in cv. Obriy mironivskiy compared to other cultivars.

The interaction of FS $x$ ST factors is one of the strongest among other interactions (exclude primeval factors), which indicates a diff erent reaction of crops of different sowing terms to the fertilizer system, ie the lack of a specific algorithm for fertilization for each variety. At the same time, the interaction of C $x$ ST and $\mathrm{C} \times \mathrm{FS}$ also significantly affects the content of chlorophyll A and B. Interaction of primeval factors at the same time was insignificant, which indicates an independent reaction of each cultivar. 
1. Content of chlorophyll A and B in flag leaf at anthesis (average 2016-2019 years)

\begin{tabular}{|c|c|c|c|c|c|c|c|c|c|}
\hline \multirow[b]{2}{*}{$\begin{array}{c}\text { Sowing } \\
\text { term }\end{array}$} & \multirow[b]{2}{*}{ Fs } & \multicolumn{7}{|c|}{ Pigment weight in dry matter } & \multirow{2}{*}{$\begin{array}{l}\text { CGR, g/ } \\
\mathrm{m}^{2} \text { per day }\end{array}$} \\
\hline & & $\mathrm{Cl}_{\mathrm{a}}, \mathrm{mg} / \mathrm{g}$ & $\mathrm{Cl}_{\mathrm{b}}, \mathrm{mg} / \mathrm{g}$ & $\begin{array}{c}\mathrm{Cl}_{\mathrm{a}}+\mathrm{Cl}_{\mathrm{b}}, \\
\mathrm{mg} / \mathrm{g}\end{array}$ & $\mathrm{Cl}_{\mathrm{a}} / \mathrm{Cl}_{\mathrm{b}}$ & $\mathrm{Cl}_{\mathrm{a}}, \mathrm{g} / \mathrm{m}^{2}$ & $\mathrm{Cl}_{\mathrm{b}}, \mathrm{g} / \mathrm{m}^{2}$ & $\underset{\mathrm{g} / \mathrm{m}^{2}}{\mathrm{Cl}}+\mathrm{Cl}_{\mathrm{b}}$, & \\
\hline \multicolumn{10}{|c|}{ Pidzimok kharkivskiy } \\
\hline \multirow{4}{*}{ I } & B1 & $6,59^{\text {cd }}$ & $1,08^{\mathrm{b}}$ & $7,67^{\mathrm{bc}}$ & 6,1 & $40,0^{\mathrm{abc}}$ & $6,5^{\text {bcd }}$ & $46,6^{\text {abcd }}$ & 4,93 \\
\hline & B2 & $6,69^{\text {cd }}$ & $1,02^{\mathrm{b}}$ & $7,71^{\text {bcd }}$ & 6,6 & $33,3^{\mathrm{ab}}$ & $5,0^{\mathrm{abc}}$ & $38,4^{\mathrm{abc}}$ & 4,47 \\
\hline & B3 & $5,88^{\mathrm{bc}}$ & $0,73^{\mathrm{a}}$ & $6,61^{\mathrm{ab}}$ & 8,1 & $28,4^{\mathrm{a}}$ & $3,5^{\mathrm{a}}$ & $31,9^{\mathrm{ab}}$ & 4,15 \\
\hline & B4 & $7,79^{\text {de }}$ & $1,48^{\mathrm{d}}$ & 9,27 de & 5,3 & $44,4^{\mathrm{abc}}$ & $8,4^{\mathrm{d}}$ & $52,8^{\text {bcd }}$ & 4,42 \\
\hline \multirow{4}{*}{ II } & B1 & $5,11^{\mathrm{ab}}$ & $0,83^{\mathrm{a}}$ & $5,94^{\mathrm{a}}$ & 6,2 & $27,3^{\mathrm{a}}$ & $4,4^{\mathrm{ab}}$ & $31,7^{\mathrm{a}}$ & 6,02 \\
\hline & B2 & $4,15^{\mathrm{a}}$ & $1,07^{\mathrm{b}}$ & $5,22^{\mathrm{a}}$ & 3,9 & $27,8^{\mathrm{a}}$ & $7,2^{\text {bcd }}$ & $34,9^{\mathrm{abc}}$ & 5,61 \\
\hline & B3 & $8,85^{\mathrm{e}}$ & $1,38^{\mathrm{cd}}$ & $10,23^{\mathrm{e}}$ & 6,4 & $48,3^{\text {bc }}$ & $7,6^{\mathrm{cd}}$ & $55,8^{\text {cd }}$ & 5,02 \\
\hline & B4 & $7,53^{\text {de }}$ & $1,30^{c}$ & $8,83^{\text {cde }}$ & 5,8 & $52,5^{\mathrm{c}}$ & $9,1^{\mathrm{d}}$ & $61,6^{\mathrm{d}}$ & 5,41 \\
\hline \multicolumn{10}{|c|}{ Amur } \\
\hline \multirow{4}{*}{ I } & B1 & $11,72^{\mathrm{d}}$ & $2,45^{\mathrm{c}}$ & $14,17^{\mathrm{e}}$ & 4,8 & $43,6^{\mathrm{a}}$ & $9,1^{\mathrm{c}}$ & $52,8^{\mathrm{b}}$ & 5,23 \\
\hline & B2 & $10,64^{\text {cd }}$ & $1,28^{\mathrm{a}}$ & $11,92^{\mathrm{cd}}$ & 8,3 & $45,3^{\mathrm{a}}$ & $5,4^{\mathrm{ab}}$ & $50,7^{\mathrm{ab}}$ & 4,64 \\
\hline & B3 & $8,31^{\mathrm{ab}}$ & $1,35^{\mathrm{a}}$ & $9,66^{\mathrm{ab}}$ & 6,2 & $40,2^{\mathrm{a}}$ & $6,6^{\mathrm{bc}}$ & $46,8^{\mathrm{ab}}$ & 4,17 \\
\hline & B4 & $8,01^{\mathrm{ab}}$ & $1,41^{\mathrm{a}}$ & $9,42^{\mathrm{ab}}$ & 5,7 & $36,1^{\mathrm{a}}$ & $6,4^{\mathrm{bc}}$ & $42,4^{\mathrm{ab}}$ & 3,93 \\
\hline \multirow{4}{*}{ II } & B1 & $8,46^{b}$ & $1,31^{\mathrm{a}}$ & $9,77^{\mathrm{abc}}$ & 6,5 & $33,9^{\mathrm{a}}$ & $5,3^{\text {ab }}$ & $39,2^{\mathrm{ab}}$ & 4,75 \\
\hline & B2 & $9,39^{\mathrm{bc}}$ & $0,98^{\mathrm{a}}$ & $10,37^{\mathrm{bc}}$ & 9,6 & $31,3^{\mathrm{a}}$ & $3,3^{\mathrm{a}}$ & $34,6^{\mathrm{a}}$ & 4,50 \\
\hline & B3 & $10,73^{\text {cd }}$ & $2,01^{\mathrm{b}}$ & $12,78^{\mathrm{de}}$ & 5,3 & $45,8^{\mathrm{a}}$ & $8,6^{\mathrm{c}}$ & $54,4^{b}$ & 4,73 \\
\hline & B4 & $6,47^{\mathrm{a}}$ & $1,16^{\mathrm{a}}$ & $7,63^{\mathrm{a}}$ & 5,6 & $43,9^{\mathrm{a}}$ & $7,9^{\mathrm{bc}}$ & $51,8^{\mathrm{ab}}$ & 5,06 \\
\hline \multicolumn{10}{|c|}{ Obriy mironivskiy } \\
\hline \multirow{4}{*}{ I } & B1 & $13,83^{\mathrm{d}}$ & $2,14^{\mathrm{d}}$ & $15,97^{\mathrm{d}}$ & 6,5 & $38,9^{\mathrm{a}}$ & $6,0^{\mathrm{ab}}$ & $44,9^{\mathrm{ab}}$ & 4,25 \\
\hline & B2 & $13,13^{\mathrm{d}}$ & $1,97^{\mathrm{cd}}$ & $15,10^{\mathrm{d}}$ & 6,7 & $43,8^{\mathrm{a}}$ & $6,5^{\text {ab }}$ & $50,4^{\mathrm{ab}}$ & 4,71 \\
\hline & B3 & $8,07^{\mathrm{ab}}$ & $1,23^{\mathrm{a}}$ & $9,30^{\mathrm{ab}}$ & 6,6 & $36,8^{\mathrm{a}}$ & $5,6^{\mathrm{a}}$ & $42,3^{\mathrm{ab}}$ & 3,95 \\
\hline & B4 & $10,60^{c}$ & $2,12^{\mathrm{d}}$ & $12,73^{\mathrm{c}}$ & 5,0 & $39,0^{\mathrm{a}}$ & $7,8^{\mathrm{bc}}$ & $46,8^{\mathrm{ab}}$ & 4,22 \\
\hline \multirow{4}{*}{ II } & B1 & $8,94^{\mathrm{b}}$ & $1,77^{\mathrm{c}}$ & $10,71^{\mathrm{b}}$ & 5,1 & $44,4^{\mathrm{a}}$ & $8,8^{\mathrm{c}}$ & $53,3^{b}$ & 4,56 \\
\hline & B2 & $6,96^{\mathrm{a}}$ & $1,11^{\mathrm{a}}$ & $8,07^{\mathrm{a}}$ & 6,3 & $41,4^{\mathrm{a}}$ & $6,6^{\mathrm{ab}}$ & $48,0^{\mathrm{ab}}$ & 3,92 \\
\hline & B3 & $7,87^{\mathrm{ab}}$ & $1,17^{\mathrm{a}}$ & $9,04^{\mathrm{ab}}$ & 6,7 & $34,0^{\mathrm{a}}$ & $5,1^{\mathrm{a}}$ & $39,1^{\mathrm{a}}$ & 3,50 \\
\hline & B4 & $8,64^{b}$ & $1,48^{\mathrm{b}}$ & $10,12^{b}$ & 5,8 & $43,7^{\mathrm{a}}$ & $9,0^{\mathrm{c}}$ & $52,7^{b}$ & 4,22 \\
\hline \multicolumn{2}{|c|}{$\mathrm{LSD}_{05}$} & 1,57 & 0,28 & 1,78 & $x$ & 14,3 & 2,48 & 16,6 & \\
\hline
\end{tabular}

CGR - crop growth rate

The weight of chlorophyll A and B per unit area $\left(\mathrm{g} / \mathrm{m}^{2}\right)$ is almost independent of the factors and their interactions, but the FS x ST relationship is significant for both the amount of chlorophyll $\mathrm{A}, \mathrm{B}$ and their sum. If the amount of chlorophyll A was almost unaffected by the main factors and their interactions, the amount of chlorophyll B significantly depended on the fertilizer system and its interaction with the varietal factor, sowing term and their combination. 


\section{ANOVA of chlorophyll content in flag leaf at anthesis}

\begin{tabular}{|l|c|c|c|c|c|c|c|}
\hline \multirow{2}{*}{ Effect } & \multirow{2}{*}{ df } & \multicolumn{6}{|c|}{ MS } \\
\cline { 3 - 9 } & & Cla, $\mathrm{mg} / \mathrm{g}$ & Cle, $\mathrm{mg} / \mathrm{g}$ & $\begin{array}{c}\mathrm{Cla}+\mathrm{B}, \\
\mathrm{mg} / \mathrm{g}\end{array}$ & $\begin{array}{c}\mathrm{Cla}, \\
\mathrm{g} / \mathrm{m}^{2}\end{array}$ & $\begin{array}{c}\mathrm{Clb}, \\
\mathrm{g} / \mathrm{m}^{2}\end{array}$ & $\begin{array}{c}\mathrm{Cla}+\mathrm{Clb}, \\
\mathrm{g} / \mathrm{m}^{2}\end{array}$ \\
\hline Cultivar (C) & 2 & $70,70^{* *}$ & $1,90^{* *}$ & $95,58^{* *}$ & $45,6 \mathrm{~ns}$ & $1,42 \mathrm{~ns}$ & $58,9 \mathrm{~ns}$ \\
\hline Sowing term (ST) & 1 & $39,87^{* *}$ & $0,72^{* *}$ & $51,31^{* *}$ & $2,6 \mathrm{~ns}$ & $4,24 \mathrm{~ns}$ & $13,6 \mathrm{~ns}$ \\
\hline Fertile system (FS) & 3 & $2,94^{*}$ & $0,54^{* *}$ & $4,66^{*}$ & $133,1 \mathrm{~ns}$ & $19,48^{* *}$ & $247,6 \mathrm{~ns}$ \\
\hline C x ST & 2 & $14,16^{* *}$ & $0,36^{* *}$ & $18,37^{* *}$ & $40,7 \mathrm{~ns}$ & $5,55 \mathrm{~ns}$ & $76,2 \mathrm{~ns}$ \\
\hline C x FS & 6 & $13,51^{* *}$ & $0,59^{* *}$ & $17,98^{* *}$ & $163,3 \mathrm{~ns}$ & $9,13^{* *}$ & $216,6 \mathrm{~ns}$ \\
\hline FS x ST & 3 & $25,18^{* *}$ & $0,84^{* *}$ & $34,85^{* *}$ & $285,3^{*}$ & $7,46^{*}$ & $374,5^{*}$ \\
\hline C x ST x FS & 6 & $1,73 \mathrm{~ns}$ & $0,19^{* *}$ & $2,44 \mathrm{~ns}$ & $118,8 \mathrm{~ns}$ & $9,23^{* *}$ & $183,7 \mathrm{~ns}$ \\
\hline Error & 48 & 0,92 & 0,30 & 1,18 & 76,0 & 2,29 & 102,0 \\
\hline
\end{tabular}

$*-\mathrm{p}<0.05 ; * *-\mathrm{p}<0.01 ; \mathrm{ns}-$ factor/interaction insignificant at $95 \%$ level $(\mathrm{p}>0.05)$;

According to the results of ANOVA and post-hoc Fisher's LSD found that plants of the first sowing term formed more photosynthetic pigments on average than the second term. The effect of the fertilizer system was manifested in a significant decrease in the content of chlorophyll A with increasing the rate to 80 and $100 \mathrm{~kg} / \mathrm{ha}$ compared to the fone, but insignificant compared to the rate of $25 \mathrm{~kg} / \mathrm{ha}$ of nitrogen.

The content of chlorophyll B decreased at the norms of 25 and $80 \mathrm{~kg} /$ ha, while it did not have a significant difference with the fone at the rates of 100 $\mathrm{kg} / \mathrm{ha}$, its content increased compared to fertilization with lower rates. Change in the amount of chlorophyll B is the plant's response to stressful conditions and the adaptation of the photosynthetic system to these changes.

It was founded in resent research (Spanic et al., 2013) that the grain yield of winter wheat does not depend on photosynthesis in optimal conditions, but on other physiological process which may

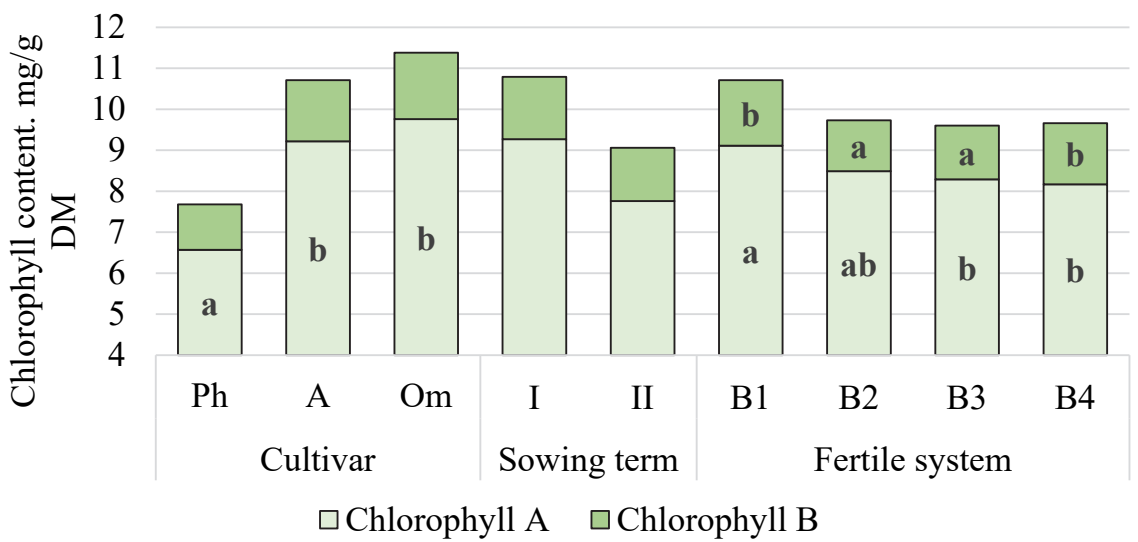

Figure 1. Chlorophyll content depends on cultivar, sowing terms and fertile system 


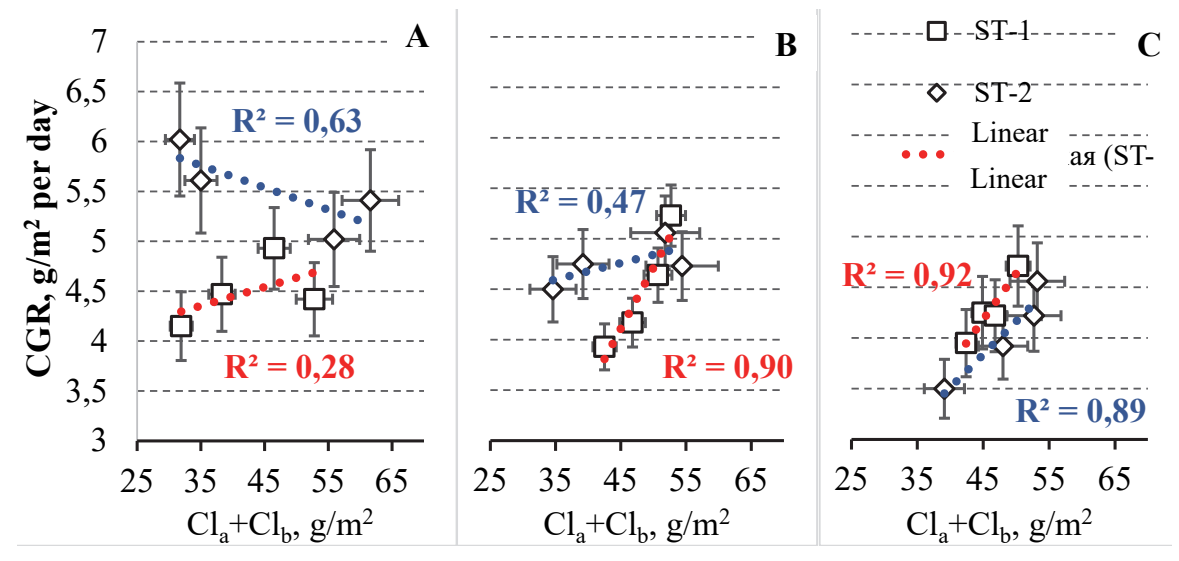

Annex. Cultivars: A - Pidzimok kharkivskiy; B - Amur; C - Obriy mironivkiy. Sowing term: ST-1 - II decade of October, ST-2 - III decade of October; means presented with standard errors (SE)

Figure 2. Relation between crop growth rate (CGR) in period "anthesis wax maturity" and chlorophyll content at anthesis

be related to the energy usage efficiency. In our research we observed a strong correlation between chlorophyll content $\left(\mathrm{Cl}_{\mathrm{a}}+\mathrm{Cl}_{\mathrm{b}}\right)$ at anthesis with dry matter accumulation after anthesis (Figure 2).

Silva et al. (2014) established that chlorophyll photosynthetic potential, characterizing the total amount of chlorophyll in the aboveground plant parts during the vegetative period under optimal environmental and climatic conditions correlated with the yield. This statement is true if the growth and development of triticale and wheat follows a typical path. In a previous study (Mazurenko \& Novytska, 2020), it was found that the accumulation of dry matter in these varieties of triticale corresponds to the normal development cycle, and the accumulation of dry matter has a strong correlation with yield. All studied cultivars has a strong positive correlation between chlorophyll content and dry matter accumulation in optimal condition (sowing term: II decade of October), but they have a difference in this relations in unfavorable conditions. Pidzimok kharkivskiy has a neg- ative correlation, when winter cultivars have a positive. The reason for this phenomenon may be a significant increase in chlorophyll in facultative triticale, which does not play a photosynthetic role, but is a reaction to stress.

\section{Conclusions and future perspectives.}

Winter cultivars have a strong positive correlation between the content of chlorophyll and the accumulation of dry matter in the post-anthesis period. At the same time, this relation differs in facultative triticale Pidzimoc kharkivskiy depend on sowing term. Fertilizer system has a significant effect on these indicators - an increase in the rate of nitrogen leads to an increase in the content of pigments, which in turn increases the CGR in winter cultivars Amur and Obriy mironivskiy. Cv. Pidzimoc kharkivskiy has high CGR values in crops of the second sowing term, so the reaction to the increase in the nitrogen rate is ambiguous, as a larger quantity of pigments does not increase the accumulation of dry matter. 


\section{References}

Akhter, M.M., Hosain, A., Timsina, J., Teixeira da Silva, A., \& Islam, M.S. (2016). Chlorophyll meter - a decision-making toll for nitrogen application in wheat under light soils. International Journal of Plant Production, 10(3), 289-302. DOI: https://dx.doi. org/10.22069/ijpp.2016.2898

Amaliotis, D., Therios, I., Karatissiou, M. (2004). Effect of nitrogen fertilization on growth, leaf nutrient concentration and photosynthesis in three peach cultivars. II International Symposium on Irrigation of Horticultural Crops. ISHS Acta Horticulturae, 449, 36-42.

Arough, Y. K., Sharifi, R. S., Sedghi, M., \& Barmaki, M. (2016). Effect of zinc and bio fertilizers on antioxidant enzymes activity, chlorophyll content, soluble sugars and proline in triticale under salinity condition. Notulae Botanicae Horti Agrobotanici Cluj-Napoca, 44(1), 116-124. DOI: https:// doi.org/10.15835/nbha44110224

Britton, G. (1983). The biochemistry of natural pigments. Cambridge University Press.

Haboudane, D., Miller, J. R., Tremblay, N., Zarco-Tejada, P. J., Dextraze, L. (2002). Intergrated narrow-band vegetation indices for prediction of crop chlorophyll content for application to precision agriculture. Remote Sensing of Environment, 81, 416-425.

Hunt R., Causton D.R., Shipley B., Askew A.P. (2002). A modern tool for classical plant growth analysis. Annals of Botany, 90(4), 485-488. DOI: https://doi.org/10.1093/aob/mcf214

Mazurenko, B., \& Novytska, N. (2020). Dry matter accumulation and photosynthesis efficiency in triticale under late autumn sowing terms and nitrogen fertilizations. Taurida Scientific Herald. Series: Rural Sciences, 111, 105-111. DOI: https://doi. org/10.32851/2226-0099.2020.111.14

Pryadkina, G. O., Makharinska N. M. (2021). Assimilation apparatus of leaves of separate tiers in wheat varieties under adverse environmental conditions. Plant physiology and genetics, № 53 (1), 74-86. DOI: https://doi. org/10.15407/frg2021.01.74

Ray Tucker, M. (2004). Primary nutrients and plant growth, In: Essential Plant Nutrients, North Carolina Department of Agriculture.

Shadchina, T.M. \& Dmitrieva, V.V. (1995). Leaf chlorophyll content as a possible diagnostic mean for the evaluation of plant nitrogen uptake from the soil. Journal of Plant Nutrition, 18(7), 1427-1437. DOI: http://dx.doi. org/10.1080/01904169509364992.

Silva, da C.L., Benin, G., Bornhofen, E., Beche, E., Todeschini, M.H. \& Milioli, A.S. (2014). Nitrogen use efficiency is associated with chlorophyll content in Brazilian spring wheat. Australian Journal of Crop Science, 8 (6), 957-964. DOI: http://dx.doi.org/10.1590/1678-4499.385

Simpson, G. M. (1968). Association between grain yield per plant and photosynthetic area above the flag-leaf node in wheat. Canadian Journal of Plant Science, (48), 253 260. https://doi.org/10.4141/cjps68-046

Spanic, V., Viljevac, M., Drezner, G. \& Lepedu's, H. (2013). Chlorophyll fluorescence parameters and grain yield of winter wheat genotypes. In 48. Hrvatski I 8. Meunarodni Simpozij Agronoma, 17-22 veljač 2013 (pp. 323-327). Dubrovnik, Hrvatska: Radova Osijeku

Tejada-Zarco, P. J., Miller, J. R., Morales, A., Berjon, A., Aguera, J. (2004). Hyperspectral indices and simulation models for chlorophyll estimation in open-canopy tree crops. Remote Sensing of Environment, 90, 463-476. DOI: https://doi.org/10.1016/j.rse.2004.01.017

Wellburn, A. R. (1994). The special determinations of chlorophyll $a$ and $b$ as well as total carotenoides using various solvents with spectrophotometers of different resolution. Journal of Plant Physiology, 144, 307-313. DOI: https://doi.org/10.1016/ S0176-1617(11)81192-2

Yang, D., Liu, Y., Cheng, H., Chang, L., Chen, J., Chai, S. \& Li, M. (2016). Genetic dissection of flag leaf morphology in wheat (Triticum aestivum L.) under diverse water regimes. BMC Genetics, 17, № 1, p. 94. 


\section{Б. О. МаЗУРенКО (2021). ПРОДУКТИВНІСТЬ ТРИТИКАЛЕ ЗАЛЕЖНО ВІД УМІСТУ ФОТОСИНТЕЗУЮЧИХ ПIГМЕНТІВ У ФАЗУ ЦВІTIННЯ. PLANT AND SOIL SCIENCE,}

12(2): 15-22. https://doi.org/10.31548/agr2021.02.015

Анотація. Фотосинтезуючі пігменти відіграють важлиу роль у накопиченні сухоі речовини іє маркерами стресу. Зміна співвідношення хлорофрілу А і В вказує на фізіологічні зміни та адаптацію організму до зміни середовища. Строк сівби і внесення азотних добрив є чинниками тривалої діï, тому вміст хлорофрілу в прапорцевому листку вказує на довготривалу адаптацію фотосинтезуючої системи. Встановлення залежності між кількістю пігментів у фазу цвітіння й накопиченням сухої речовини в період від цвітіння до воскової стиглості вказує на сортову реакцію тритикале на підживлення і строки сівби. Для встановлення цих реакцій закладався трьохфакторний дослід із вивчення озимих сортів і дворучки тритикале, 2 осінніх строків сівби й системи удобрення з підживленнями азотом у різні фази росту. Встановлено, що в кожного сорту вміст фотосинтезуючих пігментів варіював залежно від строку й системи удобрення за показниками мг на 1 г сухої речовини для хлорофрілу А В і суми А+B. Водночас різниця між факторами та їхніми взаємодіями була несуттєвою для загальної маси на одиниці площі $\left(2 / \mathrm{M}^{2}\right)$ для хлорофілу $A$ й суми $A+B$, але суттєвою для хлорофілу $B$ за фактором системи удобрення. Це вказує, що основним сигналізатором стресу є саме хлорофіл B, тому співвідношення хлорофрілу А і В суттєво різнилося залежно від цього фактору. За оптимального строку сівби співвідношення $\mathrm{Cl}_{a}$ : $\mathrm{Cl}_{b}$ становить 5,3-8,1 у Підзимку харківського, 4,8-8,3 у сорту Амур та 5,0-6,7 у сорту Обрій миронівський. Усі сорти мають сильну позитивну кореляцію між вмістом хлорофрілу у фазу цвітіння й подальшим накопиченням сухої речовини за оптимальних умов, але дворучка Підзимок харківський має негативну кореляцію за несприятливих умов, щчо пов'язано зі збільшенням хлорофілу, без збільшення накопичення сухої речовини. Подальше дослідження зв'язків між вмістом хлорофрілу й синтезом вторинних метаболітів $є$ перспективним у дослідженні сортової реакції на стрес та агротехнічні чинники.

Ключові слова: тритикале дворучка, хлорофріл, суха речовина, кореляція 